\title{
Multiparity in Adolescents: Family and Sociocultural Factors
}

\author{
A Study on Multiparity of Adolescents Between the Ages of 15 and 19 Years in Two Neighborhoods of Locality 2 in \\ Cartagena, Colombia \\ Moraima Del Toro $^{1,2}$, Yolima Manrique ${ }^{1,2}$, Keydis Ruidiaz ${ }^{3} \&$ Muna Hamdan ${ }^{2}$ \\ ${ }^{1}$ Faculty of Health Sciences, Corporacion Universitaria Rafael Nuñez, Cartagena de Indias, Colombia \\ ${ }^{2}$ Faculty of Nursing, University of Cartagena, Cartagena de Indias, Colombia \\ ${ }^{3}$ School of Nursing, Universidad del Sinú Elias Bechara Zainúm, Cartagena de Indias, Colombia \\ Correspondence: Muna Hamdan R., University of Cartagena, Cartagena de Indias, Colombia. Tel: \\ 57-301-347-0024. E-mail: mhamdanr@unicartagena.edu.co
}

Received: May 10, 2018 Accepted: August 27, 2018 Online Published: September 3, 2018

doi:10.5539/gjhs.v10n10p20 URL: https://doi.org/10.5539/gjhs.v10n10p20

\begin{abstract}
Introduction: Adolescence is a unique period of rapid growth and development in girls, that mixes the physical, emotional and social spheres of childhood and adulthood. It starts with the changes of puberty and ends when an autonomous young adult emerges.
\end{abstract}

Objective: To determine the factors related to multiparity in a certain vicinity of Cartagena, Colombia.

Methods: A descriptive cross-sectional and exploratory study, consisting of 207 adolescents aged between 15 and 19 years residing in locality 2 in Cartagena.

Results: The average age of the adolescents surveyed was 18.32 years. It was found that teenagers' will to have 2 children (with respect to having 3 ) is lower (in 0.175) in girls with an educational level higher than primary school. When a family is moderate in giving orders or rules, the chance of a teen to have 2 children instead of 3 is 3.95 times higher than in those families that are not moderate. When planning the first pregnancy, the desire of adolescents to have a second child and not a third is 17.607 higher these girls that had unplanned first in those in which their first pregnancy was not planned. Whereas in pregnancies due to the misuse of contraceptives, the probability of not conceiving a third child is 3.7 times higher than those who became pregnant for a different reason. Adolescents who attended prenatal controls have a preference of 0.021 for having 4 or more children instead of 3, with respect to those who do not attend.

Conclusions: A series of family and sociocultural factors were identified in this study, that relate to multiparity in adolescents. The family is the core unit of health and the ideal entity to convey protective factors.

Keywords: multiparity, adolescents, family, sociocultural factors

\section{Introduction}

Adolescence is a unique period of rapid growth and development, comprising the physical, emotional and social scopes of childhood and adulthood. It starts with the changes of puberty and ends when an autonomous young adult emerges, an individual who can function responsibly at an intellectual and sexual level, and with vocations that benefit society (Secretaria, 2002). The World Health Organization defines adolescence as a "period of life in which the individual acquires reproductive capacity, turns from the psychological patterns of childhood into adulthood, and consolidates his or her socioeconomic independence ", setting its limits between 10 and 20 years (Issier, 2001), during this stage of biological and psychological development, big changes are experienced shaping in many cases the beginning of his or her sex life, becoming this last point a topic of interest because of their little to no experience turning their lives around, facing social problems such as early pregnancies or even acquiring Sexually Transmitted Diseases (STDs) (Serrano et al., 2015).

Today, teenage pregnancy is considered a global public health problem (Noguera \& Alvarado, 2012), as well as an indicator of poverty, due to its negative repercussions to the economy, family and collective environment, forcing responsibilities that are not accord to their age, and leading to their failure in aspects of independence, personal identity, studies, building a stable family, and consequently preparing for their adulthood (Knudson, 2013). 
In 2014, a study in Latin America showed that $19.5 \%$ of females between the ages of 15 and 19 years were or had been pregnant (Fondo de Población de las Naciones Unidas, 2014), countries such as Argentina in 2011 reported a total of 107 girls between 10 and 14 years' old that were mothers for the second time, and 20 girls for the third time. These 127 cases show the multiple failures of the society as a whole, blaming the healthcare services and their policies to act in a timely manner. (Tantera et al., 2017)

In Colombia, the city of Cartagena holds an average age of 17 years old of teenage girls having repeated pregnancies of two to three children (Knudson, 2013). The National Health and Demography Survey (NHDS) 2015 (Profamilia. Instituto Nacional de Salud. Ministerio de Salud y Protección Social, 2015) estimated that the fertility rate in the 15 to 19 year-old group dropped to 74 per thousand in 2015 with respect to the year 2005, which was 90 per thousand. While the time space between consecutive pregnancies did increase in the country with a median of 50.7 months comparing it to the year 2010 which was 47.5 (Profamilia. Instituto Nacional de Salud. Ministerio de Salud y Protección Social, 2015).

It is noted that older women with better economic conditions have more leisure or intergenic periods between the pregnancy periods. On the other hand, young women between the ages of 15 and 19 who live in rural areas and have low educational level, have less probabilities to obtain wealth and consequently have intergenic periods under 23.6 months between their pregnancies (Profamilia. Instituto Nacional de Salud. Ministerio de Salud y Protección Social, 2015).

Decades ago, it was normal to find large families. However, the fertility rate has systematically declined from 6.7 children per woman in 1967 to 2.1 in 2010 (Profamilia. Instituto Nacional de Salud. Ministerio de Salud y Protección Social, 2010) and for the year 2015 the NHDS reported the global fertility rate of 2 children per woman (Profamilia. Instituto Nacional de Salud. Ministerio de Salud y Protección Social, 2015). These children are conceived in very short periods in between, generating medical complications during pregnancy such as: malnutrition, perinatal and maternal mortality, psychological affectations and disturbance of future plans (Berlofi et al., 2006). Due to the reoccurrence of pregnancies in teenagers between the ages of 15 and 19, social aspects that have a big influence on multiparity such as the family and the culture were pointed out. Authors like Coard (Coard, 2008), and Gonzáles (González, 2003) state that multiparity occurs in $73.5 \%$ of women who do not use contraceptives during the postpartum period, as well as the good attitude taken by their families, who provided them with emotional and economic support during the subsequent gestation. Lammers (2000) mentions that adolescents who are more likely to have a second pregnancy come from families where there was a positive reaction to the first one.

It is important to invest time and effort in the adolescent population; this group contributes to global progress. Multiparity is a relevant health problem that generates repercussions on sexual and reproductive health policies, family planning programs and even to the health system itself. Therefore, national health entities stir their approach to the healthcare system, in order to decrease the fertility rate in teenage girls, thus, promoting and monitoring sexual and reproductive health programs, and presenting to them new perspectives of life.

\section{Methods}

A descriptive, cross-sectional and exploratory study. The population corresponded to a demographic group of adolescents aged 15 to 19 years residing in the neighborhood of Locality 2 in the city of Cartagena (see Figure 1). The study consisted of 207 adolescents (confidence level of $95 \%$ and sampling error of $6.8 \%$ ), selected through probabilistic sampling for convenience. Teenagers between 15 and 19 years of age were considered as the inclusion criteria; with 2 or more children; residents in the neighborhoods of the mentioned location; and with the desire to participate in the investigation. 


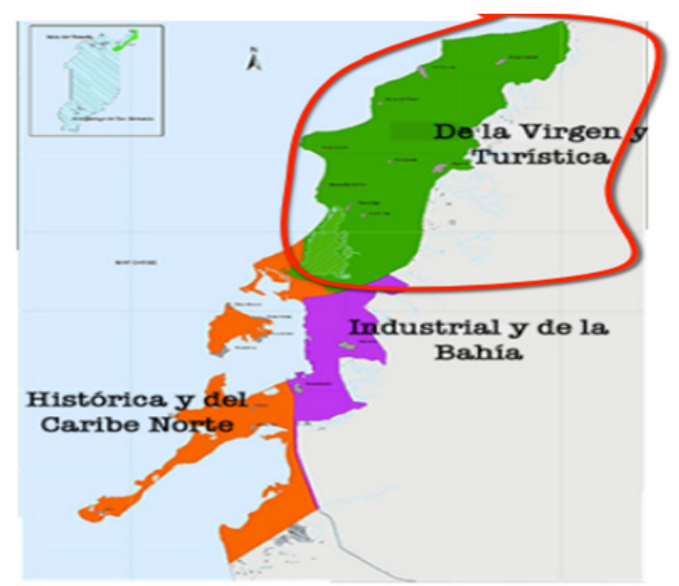

Figure 1. Locality 2 (de la virgen y turística)

Source: Funcicar Foundation- Cartagena

The researchers designed a questionnaire named "Family and Sociocultural Factors Associated with Multiparity of Adolescents", in order to collect the data. It consisted of 21 items divided into 2 parts; the first evaluated sociodemographic aspects ( 8 items) and the second dealt with family and cultural factors (13 items). Assessed by an expert, the context and the items questioned met the criteria established for validation. The questionnaire has an Alpha Cronbach reliability index equal to 0.60 determined through a pilot test.

The data was processed in Microsoft Excel ${ }^{\circledR}$ spreadsheet for further analysis in the SPSS $21{ }^{\circledR}$ statistical program licensed to the research group. Results were analyzed using descriptive and inferential statistics techniques, which included the calculation of averages, mode, median, as well as dispersion measures such as standard deviation, variance and percentages. The association was estimated through a statistical technique called multi-nominal logistic regression used to estimate distribution probabilities for each individual $i$. considering the set of explanatory variables (Flores Peña et al., 2007); in other words, this categorized response model takes the dependent variable- in this case the Multiparity present in a set of possible answers (in this case it is: " 2 ". " 3 " and "4 or more children") from which we want to estimate the probability that the adolescent present or not an event of these events- given a set of variables that explain this phenomenon. The Stata 8.0 software was used and the model of interest was specified using the m-logit function.

With respect to the ethical considerations, the project was adjusted to Resolution \# 008430 of 1993 (República de Colombia. Ministerio de Salud, 1993) of the Colombian Ministry of Health, considering the research as risk-free while maintaining the privacy and reliability of the information provided, for which the informed consent was applied to the parents of the non-emancipated minors and the assent to the adolescents who depend economically on their parents.

\section{Results}

The average age of the adolescents surveyed was 18.32 years (95\% CI: $18.21-18.42)$ with a low standard deviation ( 0.78 years), the highest percentage of adolescents being 19 years old $44.9 \%$, followed by 18 years with $43.5 \%$ and in lower proportion those of 15 years $(0.96 \%)$.

The educational level was characterized by having secondary education estimated at $62.7 \%$, noting that the professionals had the lowest participation with a percentage of $1.4 \%$. When relating the educational level with the age range we found that $57.1 \%$ of the individuals were 18 years old, although others within the same level were 19 years old $35.7 \%$. Regarding secondary education, the participation was relatively similar with $46.9 \%$ and $42.2 \%$, respectively.

The type of family that predominated was the nuclear one with $53.5 \%$. Multiparity prevailed in families with 2 children corresponding to $77.0 \%$ where mothers were between $15-19$ years. The subjects came from the urban area $(98.1 \%$ ) having a free union status $77.0 \%$ and no employment $84.7 \%$ (see Table 1). On average, the menarche occurred at 12.07 years $(95 \% \mathrm{CI}: 11.89-12.24)$ and the median was 12 years. 
Table 1. Sociodemographic characteristics of adolescents aged 15 - 19 years.

\begin{tabular}{|c|c|c|c|}
\hline Items & & Frequency & Percentage \\
\hline \multirow{6}{*}{ Age } & 15 & 2 & 1.0 \\
\hline & 16 & 5 & 2.4 \\
\hline & 17 & 13 & 6.2 \\
\hline & 18 & 91 & 43.4 \\
\hline & 19 & 94 & 45.0 \\
\hline & System & 4 & 2.0 \\
\hline \multirow{5}{*}{ Educational level } & Primary & 14 & 6.7 \\
\hline & High school & 131 & 63.0 \\
\hline & Technical ed. & 23 & 11.00 \\
\hline & Professional & 3 & 1.3 \\
\hline & Does not know & 38 & 18.0 \\
\hline \multirow{6}{*}{ Family Type } & Nuclear & 112 & 53.6 \\
\hline & Extended & 75 & 35.8 \\
\hline & Single parent & 3 & 1.3 \\
\hline & Superimposed & 4 & 2.0 \\
\hline & Other & 6 & 3.0 \\
\hline & System & 9 & 4.3 \\
\hline \multirow{4}{*}{$\#$ of children } & 2 & 161 & 77.0 \\
\hline & 3 & 35 & 17.0 \\
\hline & 4 or more & 11 & 5.0 \\
\hline & System & 2 & 1.0 \\
\hline \multirow{2}{*}{ Origin } & Rural & 205 & 98.0 \\
\hline & Urban & 4 & 2.0 \\
\hline \multirow{3}{*}{ Marital Status } & Married & 10 & 5.0 \\
\hline & Separated & 38 & 17.0 \\
\hline & Free Union & 161 & 77.1 \\
\hline \multirow{3}{*}{ Occupation } & Employee & 16 & 8.0 \\
\hline & Independent & 16 & 8.0 \\
\hline & Unemployed & 177 & 84.0 \\
\hline \multirow{8}{*}{ Menarche age } & 9 & 5 & 2.5 \\
\hline & 10 & 11 & 5.4 \\
\hline & 11 & 49 & 23.4 \\
\hline & 12 & 60 & 28.7 \\
\hline & 13 & 37 & 17.7 \\
\hline & 14 & 31 & 14.8 \\
\hline & 15 or more & 15 & 7.1 \\
\hline & System & 1 & 0.4 \\
\hline
\end{tabular}

Source: questionnaire Family and Sociocultural Factors associated with the Multiparity of Adolescents.

Additional information was obtained during the study on how these adolescent perceive their communication with 
their family; the results were good $67.9 \%$, regular $31.1 \%$, and bad $1 \%$. Adolescents rated their families as moderate at the moment of imparting norms or rules, commitments, etc. (46.9\%), it was also observed that others evaluated them as flexible (37.3\%), rigid (12.9\%) and judgmental $(2.9 \%)$.

In the survey, the girls declared that within the family relationships the most relevant decisions in any field were made together as a family in $77.9 \%$ of the cases, the feeling of satisfaction due to the support they received from their families in terms of the time they shared and money provided was $88.9 \%$. On the other hand, discontent or upset feelings were expressed by the remaining $11.1 \%$. However, the assessment regarding the item (support or attitude present in the family at the time of the first pregnancy) was rated "good" by most of the participants in the study, that is $61.2 \%$, although others pointed out that such support in some cases was regular or bad $25.4 \%$ and $12.4 \%$ respectively.

The age at which the first sexual intercourse was held had the following responses, at the age of $1533.7 \%$, at the age of $16(22.1 \%)$ and at the age of $14(16.8 \%)$. Some statistical parameters were calculated for the age variable of the first sexual relationship, finding that the average age was 14.93 years (95\% CI: 14.75-15.12).

The most common source of information on contraceptive methods was in school facilities $55.6 \%$, followed by clinics, friends and health personnel, each with proportions of $15.1 \% .11 .1 \%$ and $7.9 \%$ respectively.

The teenagers stated that their pregnancy was due in most cases to misuse of contraceptives (36.4\%). Although a different percentage indicated that it was planned $(30.1 \%)$. While the remaining attributed to the lack of knowledge (26.7\%). moreover, adolescents indicated living with their partner and their partners $(55 \%)$, staying at their mother's (15. 8\%), with both mother and father (12.4\%) and with other relatives (12\%). After knowing their pregnancy status, most of the adolescents indicated that they attend prenatal controls $96.1 \%$. Conversely, a very small portion $3.9 \%$ pointed out that their pregnancy had no prenatal controls, putting their life and that of the fetus at risk.

Finally, the girls that their attitude towards the second pregnancy was generally of surprise $(60.4 \%)$, few felt disappointed (6.8\%), depressed (6.8\%) and or desperate (9.2\%).

\subsection{Factors Correlated With Multiparity in Adolescents}

Table 2. Multinomial logistic regression of the multiparity determinants.

\begin{tabular}{|c|c|c|c|c|c|}
\hline \multirow[b]{2}{*}{ Factors } & \multirow[b]{2}{*}{ Variable } & \multicolumn{2}{|l|}{2 sons } & \multicolumn{2}{|l|}{4 or more } \\
\hline & & $\begin{array}{l}\text { Relative } \\
\text { risk }\end{array}$ & $\begin{array}{l}p \\
\text { value }\end{array}$ & $\begin{array}{l}\text { Relative } \\
\text { risk }\end{array}$ & $\begin{array}{l}p \\
\text { value }\end{array}$ \\
\hline \multirow{2}{*}{ Education } & Primary schooling & 0.175 & 0.007 & 6.310 & 0.280 \\
\hline & Secondary schooling & 0.591 & 0.331 & 0.064 & 0.046 \\
\hline \multirow{11}{*}{ Family } & The communication between you and your family is good & 0.000 & 0.856 & - & - \\
\hline & Communication between you and your family is regular & 0.001 & 0.858 & - & - \\
\hline & Conflicts and discussions in the family sometimes occur & 1.366 & 0.544 & 93862.120 & 0.886 \\
\hline & The family when giving orders or rules is flexible & 1.818 & 0.372 & 60795.800 & 0.886 \\
\hline & The family when giving orders or rules is moderate & 3.950 & 0.008 & 64131.590 & 0.886 \\
\hline & $\begin{array}{l}\text { Satisfied with the support she receives from the family regarding the } \\
\text { time they share and the money }\end{array}$ & 3.063 & 0.209 & 0.312 & 0.599 \\
\hline & Important decisions are made jointly with the family & 0.247 & 0.086 & 4.017 & 0.504 \\
\hline & $\begin{array}{l}\text { The support or attitude of the family before the first pregnancy was } \\
\text { good }\end{array}$ & 0.000 & 0.951 & - & - \\
\hline & $\begin{array}{l}\text { The support or attitude of the family before the first pregnancy was } \\
\text { regular }\end{array}$ & 0.000 & 0.954 & - & - \\
\hline & The support or attitude of the family before the first pregnancy was bad & 0.000 & 0.947 & - & - \\
\hline & $\begin{array}{l}\text { She received information about some contraceptive method before the } \\
\text { first pregnancy }\end{array}$ & 1.730 & 0.37 & 0.260 & 0.418 \\
\hline
\end{tabular}




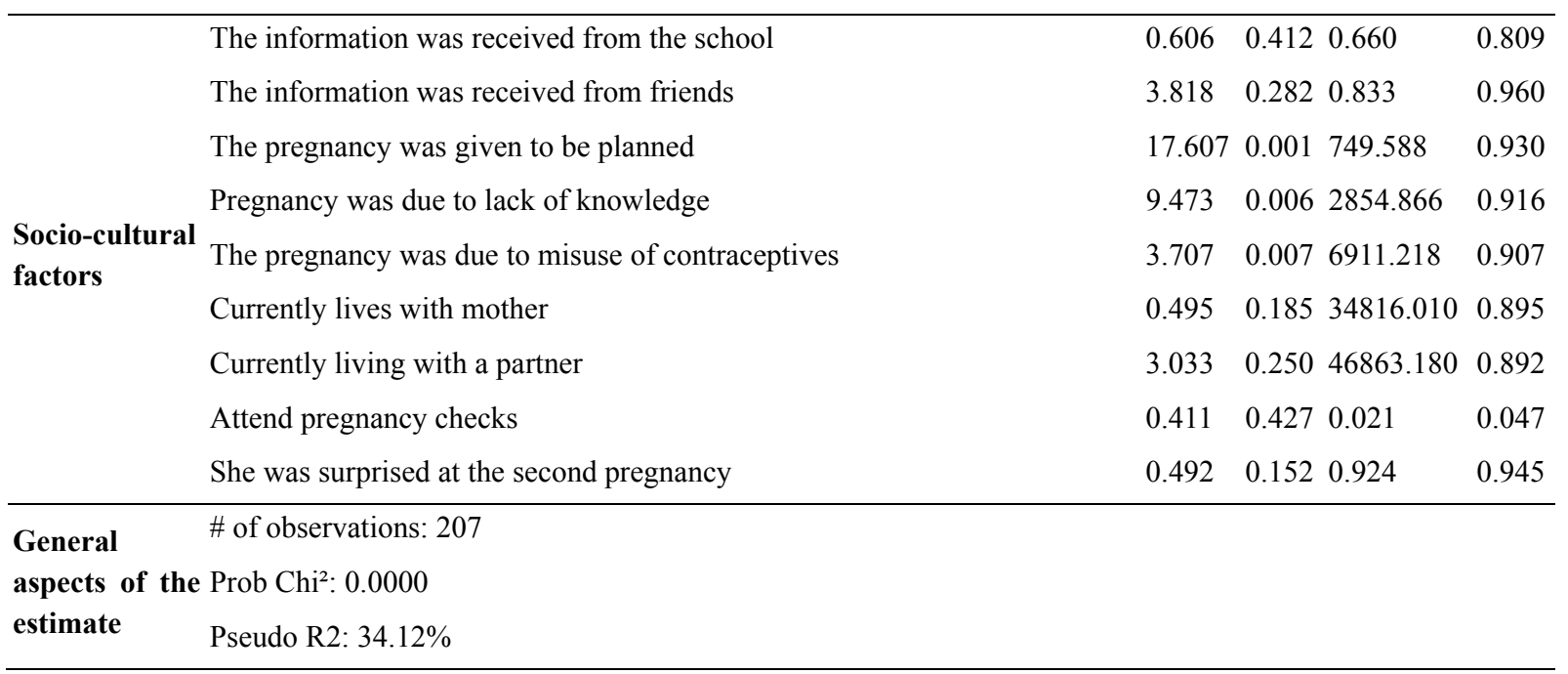

Source: questionnaire Family and Sociocultural Factors associated with the Multiparity of Adolescents.

The interpretation of Table 2 is given first in general terms, referring to the statistical significance of the model, that according to the chi square probability value can be said to be significant, since Prob Chi²: 0.0001 was less than 0.05 , which also indicates that all variables do not present all values equal to zero simultaneously. The adjustment of the model was relatively good, obtaining a $34.12 \%$ in other words, this means that all the included variables explain the multiparity in that percentage.

Regarding the individual interpretations, the following explains each model:

In the survey it was found that primary schooling was significant, which can be understood as the preference for a teenager to have 2 children (with respect to having 3 ) is lower (in 0.175) in girls with an educational level higher than primary school, meaning those who have only higher training are likely to have 2 children instead of 3 .

When a family is moderate in giving orders or rules, the preference (or relative risk) of a teen to have 2 children instead of 3 is 3.95 times higher than in those families that are not moderate.

If the first pregnancy was planned, the preference of adolescents to have a second one and not a third is 17.607 higher than in those in which their first pregnancy was not planned.

Also, when the pregnancy was due to the misuse of contraceptives. the probability of not conceiving a third child is 3.7 times higher than those who had pregnancy for a different reason.

It was observed that adolescents prefer having 4 or more children instead of 3 in a proportion of 0.06 when they have secondary education than when they don't. That is, given that 0.06 is less than 1 , the preference is more inclined because those with education other (lower) than secondary have 4 or more instead of 3 children.

The second and last variable that were important corresponded to the prenatal controls. In this situation, an adolescent who attended had a preference of 0.021 for having 4 or more children instead of 3 , with respect to one that didn't attend. That is, those who do not attend are more likely to have 4 or more children than those who do (see Table 2).

\section{Discussion}

This research as well as the demographic and epidemiological studies, provide evidence that over the years the first sexual intercourses take place in younger teenagers, that is, the earlier the first intercourse occurs, the greater the number of sexual partners that these females may have, increasing the risk of multiple pregnancies and STDs (Mendoza \& Arias, 2012).

Several studies show that the onset age of sexual activity occurs around 16 years (Marchetti, Rodríguez, \& Rodríguez, 2006). PROFAMILIA in its Demography and Health Survey shows that this is a little higher at 18.1 years in 2010 (PROFAMILIA, 2010), on the other hand, an initial age of onset of 16.6 years has been estimated among Cartagena citizens (16-23 years) surveyed in a study in 2012 (Díaz, Arrieta, \& González, 2014). In general, 14.93 years is the actual average onset of sexual relations in teenage girls from the vicinity La Sierrita and Nelson Mandela, which suggests an obvious early start of relationships that sooner or later will have repercussions on these women's lives. 
Such repercussions include emotional, health, economic, school and work-related problems for these young mothers and their children. This was similarly described by other authors, who also gave examples of the consequences of early sexuality and motherhood in adolescence, such as problems for educational and personal development, health risks, and the loss of potential productive individuals that can benefit our society (Silber, Giurgiovich, \& Munist, 2005; Mendoza, Arias, \& Mendoza, 2012). Holguín and colleagues (Díaz \& Varas, 2007) indicated that teenage mothers and their children are more prone to preeclampsia, preterm labor, prematurity, bacterial infections, syphilis and neonatal mortality.

According to (Díaz \& Vara, 2007) a hidden issue that the literature oversees is the psychological and sociocultural problem that multiparity brings to adolescents. In line with the recommendation of these authors, this research aimed to evaluate and assess the problem, although indirectly, since the arrival of a second and even a third child during adolescence is a reality, as is also the so-called "circle of poverty" where the new member is a cause of socio-economic concern for the family.

Moreover, we found that a significant proportion of the adolescents surveyed had no previous information on contraception. While those who did reported that it came mainly from school, and almost never from their homes. This result was consistent with that found by Campos (Campos \& Fajardo, 2000) and Moura (Moura \& Gomes, 2014) who stated that it is evident that schools and families have always reserved these discussions and procrastinated in giving information on sexuality and contraception; and in the best of cases focused on providing information about the anatomy and physiology of both genders.

Among the factors that affect multiparity, it was pointed out that low educational level encourages multiparity in particular. Adolescents with only primary and secondary education are likely to have more than 2 children, which is a critical finding in light of the aforementioned consequences of having children in the context of poverty and poor quality of life.

This could be reinforced by the fact that the teenager's family did not assume the authority that they own. This was detected in the results, given that their families were rated as moderate -by the majority of adolescents at the time of giving norms or rules to fulfill duties commitments. In fact, there was also a significant number of those who responded that their families were flexible. However, there were proportionally few assessments of rigid families (Moura et al., 2011). This is supported by Gonzalez (González et al., 2003), who affirmed that family cohesion is one of the central dimensions of family dynamics, understanding the emotional bonds that family members have with each other and the degree of personal autonomy they experience, measured in terms of more frequent and close relationships between them. This is generally expressed in attitudes of mutual support, carrying out activities together and reciprocal affection.

The fact of having information about contraceptive methods constitutes an important tool when it comes to preventing unwanted pregnancies. The lack of knowledge in relation to the use of contraceptives weighs on the fact that they have two or more children. These results confirm what Yu-Tang (Yu-Tang, 2000) and Moccellin (Moccellin et al., 2010) reported; the lower the educational level is, the younger the age of conception. The lack of information on contraceptive methods can lead to frequent pregnancies during a short period of time, meaning multiparity.

\section{Conclusion}

A series of family and sociocultural factors related to the occurrence of multiparity in adolescents, were identified. The family is the core unit of health, which must be educated with norms and limits exercising an affective, shared, and responsible authority, being also the ideal entity to convey protective factors. Within this task is the role of parents as educators of sexuality, who act as agents of socialization, modeling their attitudes and behaviors so children can learn from them.

This study analyzed the factors associated with multiparity, particularly in adolescents, who were around 18-19 years old, having secondary education, with extended and nuclear families, coming from urban areas, living in free union as their marital status, unemployed, had their menarche when they were around 11-13 years old, and finally their multiparity usually referred to having had 2 children.

We highlight among the family aspects the following; family interaction as a symbol of good communication (Domínguez, González, \& Vega, 2009) and acceptance of teenage pregnancy supported by flexible relationship and good family attitude.

The sociocultural aspects include or gather influences coming from the society and gestated in a culture that infuses the character, the customs and the daily life of these adolescents, resulting in diverse behaviors. The fact of having initiated sexual relations at an early age, and receiving vague information about some contraceptive 
methods in schools, makes a notable difference form those who didn't receive any. Therefore, it was established that pregnancy was due in most cases to misuse of contraceptives, although there were also cases in which it was planned, others had no knowledge of it.

Finally, this research contributions are expected to be the basis for the implementation of new strategies and interventions, that decrease the prevalence of multiparity, especially in the vulnerable population of Cartagena. We recommend to carry out strategic alliances with the educational institutions, youth and adolescents, as well as a decent training in sexually transmitted diseases, and of course the importance of attending prenatal care consultations.

\section{Acknowledgments}

We thank the people who participated and made this study viable.

\section{Competing Interests Statement}

The authors declared that there was no conflict of interest during this investigation. The study had no personal, financial or political ties to the entities or individuals surveyed.

\section{References}

Berlofi, L. M., Alkmin, E. L. C., Barbieri, M., Guazzelli, C. A. F., \& Araujo, F. F. D. (2006). Prevenção da reincidência de gravidez em adolescentes: efeitos de um Programa de Planejamento Familiar. [The effectiveness of an educational family planning program in preventing the recurrence of teen pregnancy]. Acta Paul Enferm, 19(2), 196-200. https://doi.org/10.1590/S0103-21002006000200011

Campos, R., \& Fajardo, M. D. M. P. (2000). Conocimientos y prácticas anticonceptivas en adolescentes embarazadas. Revista del Hospital General Dr. Manuel Gea González, 3(2), 56-59.

Coard, S. (2008). Predictors of Repeat Pregnancy in Urban Adolescent Mothers. Journal of Adolesc Health, 22(2), 173. https://doi.org/10.1016/S1054-139X(97)83259-4

Díaz-Cárdenas, S., Arrieta-Vergara, K., \& González-Martínez, F. (2014). Prevalencia de actividad sexual y resultados no deseados en salud sexual y reproductiva en estudiantes universitarios de Cartagena, Colombia, 2012. Revista Colombiana de Obstetricia y Ginecología, 65(1), 22-31. https://doi.org/10.18597/rcog.76

Díaz. A., \& Varas. J. (2007). Partos en adolescentes periodo 2003-2005. Rev. Obstet. Ginecol. Hosp. Santiago Oriente Dr. Luis Tisné Brousse. 2007; 2(2), 104-108. Retrieved from http://www.revistaobgin.cl/articulos/ver/429

Flores Peña, E., Sinha, S., \& Nava Puente, L. A. (2007). Modelo de regresión logística multinomial y análisis de correspondencias múltiple: un estudio de la siniestrabilidad en el IPP-ULA. Actualidad Contable Faces, 10(14), 51-67. Retrieved from_http://www.redalyc.org/pdf/257/25701406.pdf

Fondo de Población de las Naciones Unidas. (2014). Prevención del embarazo adolescente: Una mirada completa. UNFPA: America Latina y El Caribe. Retrieved from http://www.codajic.org/sites/www.codajic.org/files/Embarazo\%20Adolescente\%20\%20Medell\%C3\%ADn \%202011.pdf

Gázquez, M. D. L. Á. R. (2008). Factores de riesgo para embarazo adolescente. Medicina upb, 27(1), 47-58. Retrieved from_http://www.psicothema.com/psicothema.asp?id=1090

González, E., Encina, C., Gómez, M., Molina, T., \& Sandoval, J. (2003). Factores psicosociales que se asocian a la reincidencia del embarazo en adolescentes chilenas. In Contribución a Congreso Sogia. Rev Sogia (Vol. 10, pp. 71-2). Retrieved from_http://www.psicothema.com/psicothema.asp?id=1090

Holguín, Y. P., Mendoza, L. A., Esquivel, C. M., Sánchez, R., Daraviña, A. F., \& Acuña, M. (2013). Factores asociados al inicio de la actividad sexual en adolescentes de Tuluá, Colombia. Revista chilena de obstetricia y ginecología, 78(3), 209-219. https://doi.org/10.4067/S0717-75262013000300007

Issier, R. J. (2001). Embarazo en la adolescencia. Revista de Postgrado de la Cátedra de Medicina. Agosto, (7), 11-23.

Knudson, M. L. (2013). Causas de reincidencia de embarazos en las adolescentes asociados al conocimiento sobre los servicios en salud sexual y reproductiva en tres barrios del distrito de Cartagena enero a julio de 2013 (Tesis, Colombia: Universidad de Cartagena. Facultad de Ciencias económicas. Especialización en $\begin{array}{lllll}\text { Gerencia en } & \text { Salud. } & \text { Rima). } & \text { from }\end{array}$ http://190.242.62.234:8080/jspui/bitstream/11227/2857/1/Tesis\%20Iliana\%20Knudson\%20y\%20Luzney\%2 
0Mart\%C3\%ADnez\%5B1\%5D.pdf

Lammers, C. (2000). Adolescencia y embarazo en el Uruguay. Joven. pobre y embarazada: antecedentes y estrategias para mejorar la situación y el futuro de las madres adolescentes. Montevideo: MSP. Retrieved from http://files.luisavarela.webnode.es/200000171-8e7cd8ef2e/Adolescencia\%20y\%20embarazo\%20en\%20Uru guay.pdf

Marchetti, R., Rodríguez, G., \& Rodríguez, A. (2006). Los adolescentes y el SIDA: La importancia de la educación para la prevención. SIDA-FTS, 2, 61-69.

Moccellin, A. S., Costa, L. R., Toledo, A. M. D., \& Driusso, P. (2010). Efetividade das ações voltadas à diminuição da gravidez não-planejada na adolescência: revisão da literatura. Retrieved from http://www.scielo.br/scielo.php?script=sci_abstract\&pid=S1519-38292010000400002\&lng=pt\&nrm=iso\&tl $\mathrm{ng}=\mathrm{pt}$

Mendoza, L. A., Arias, M., \& Mendoza, L. I. (2012). Hijo de madre adolescente: riesgos, morbilidad y mortalidad neonatal. Revista chilena de obstetricia y ginecología, 77(5), 375-382. https://doi.org/10.4067/S0717-75262012000500008

Mendoza, L. A., Arias, M., Pedroza, M., Micolta, P., Ramírez, A., Cáceres, C., ... \& Acuña, M. (2012). Actividad sexual en adolescencia temprana: problema de salud pública en una ciudad colombiana. Revista chilena de obstetricia y ginecología, 77(4), 271-279._https://doi.org/10.4067/S0717-75262012000400006

Moura, L. N. B. D.. \& Gomes. K. R. O. (2014). Planejamento familiar: uso dos serviços de saúde por jovens com experiência de gravidez. Ciência \& Saúde Coletiva, 19, 853-863. https://doi.org/10.1590/1413-81232014193.10902013

Menkes, C., \& Suárez, L. (2003). Sexualidad y embarazo adolescente en México. Papeles de población, 9(35), 233-262. https://doi.org/10.1590/S0103-21002011000300003

Noguera, N., \& Alvarado, H. (2012). Embarazo en adolescentes: una mirada desde el cuidado de enfermería. Revista Colombiana de enfermería, 7(7), 151-160.

Padin, M. D. F. R., e Silva, R. D. S., Chalem, E., Mitsuhiro, S. S., Barros, M. M., Guinsburg, R., \& Laranjeira, R. (2009). Brief report: A socio-demographic profile of multiparous teenage mothers. Journal of adolescence, 32(3), 715-721. https://doi.org/10.1016/j.adolescence.2009.01.008

Profamilia. Instituto Nacional de Salud. Ministerio de Salud y Protección Social. (2015) Encuesta Nacional de $\begin{array}{lllll}\text { Demografía } & \text { y } & \text { Salud. } & \text { ENDS-2015. } & \text { Retrieved }\end{array}$ http://profamilia.org.co/docs/ENDS\%20\%20TOMO\%20I.pdf

Profamilia. Instituto Nacional de Salud. Ministerio de Salud y Protección Social. (2010)Encuesta Nacional de Demografía y Salud. ENDS-2010. Retrieved from https://dhsprogram.com/pubs/pdf/fr246/fr246.pdf

PROFAMILIA. (2010). [Internet] Edad a la Primera Relación Sexual. ENDS. [citado 29 Ago 2014]. Disponible en: Retrieved

from http://www.profamilia.org.co/encuestas/Profamilia/Profamilia/index.php?option=com_content\&view=articl e\&id $=46 \&$ Itemid $=74$

República de Colombia. Ministerio de Salud. (1993). Resolución No. 8430. octubre 4. por la cual se establecen las normas científicas. técnicas y administrativas para la investigación en salud. [Internet]. Bogotá D.C.: Minsalud. Retrieved

from https://www.minsalud.gov.co/sites/rid/Lists/BibliotecaDigital/RIDE/DE/DIJ/RESOLUCION-8430-DE-199 3.PDF

Secretaria De Salud. (2002). Prevención De Embarazos No Planificados En Las Adolescentes. Segunda Edición. p 30-36

Serrano. M.. et al. (2015). Visualización de factores que contribuyen a más de un embarazo en la adolescente. Berazategui. Buenos Aires: s.n. Retrieved from http://www.fasgo.org.ar/images/Embarazo_Adolescente_Premio.pdf

Silber, T., Giurgiovich, A., \& Munist, M. (2005). El embarazo en la adolescencia. Organización Panamericana de la Salud. La salud del adolescente y del joven. Washington. D.C.: OPS.

Tantera S et al (2017) Reinicidencia de embarazo adolescente. Rev. Hosp. Mat. Inf. Ramón Sardá, 3(2), 106-118. 
Yu-Tang, J. (2000). Complicaciones Perinatales y Vía de Parto en Recién Nacidos de Madres Adolescentes Tempranas y Tardías, 1995-1997. In Anales de la Facultad de Medicina (Vol. 61, No. 1). Universidad Nacional Mayor de San Marcos. Retrieved from http://sisbib.unmsm.edu.pe/BVRevistas/Anales/v61_n1/pdf/a07v61n1.pdf

\section{Copyrights}

Copyright for this article is retained by the author(s), with first publication rights granted to the journal.

This is an open-access article distributed under the terms and conditions of the Creative Commons Attribution license (http://creativecommons.org/licenses/by/4.0/). 